\title{
Determinants of Academic Staff Turnover Intention in case of Bonga University
}

\author{
Biniam Getnet ${ }^{1}$, Amanuel Shibiru ${ }^{2}$ \\ ${ }^{1}$ MBA Scholar, Department of Management, Bonga University \\ ${ }^{2}$ MBA Scholar, Department of Management, Bonga University \\ *Correspondence: e-mail@e-mail.com; Tel.: biniamgetnet1@gmail.com,yogesaman@gmail.com
}

\begin{abstract}
In Academic Staff retention is one of the challenges facing several University in both the developed and developing countries of the world. The purpose of this study is to investigate the determinants of Academic Staff Turnover Intention in case of Bonga University. The study measured determinants and its relation with Turnover intention in the Bonga University. The sample consisted of 157 respondents' selected based on random sampling procedure. Primary data were collected by using 5-point Likert scale questionnaire. The result of the study showed that determinants; External factors have strong influence on Academic Staff Turnover Intention and weak impact with personal and Internal factors to Turnover Intention at Bonga University. The correlation results indicate that there is a positive correlation between the determinants and Turnover Intention. The results of the regression test showed that External factors have significant on Turnover intention. Thus, the determinants affect turnover intention that have not improve in order to maximizing academic programs and working conditions, working with city administration in order to facilitate better living and recreation centres, solving house problem staff and facilitating good education for children. The prevalence of academic staff intending to leave was found to be moderate and as a result, Before the intention is going to high rate take action in order to fill gaps of external factors the result presented and there should be staff retention mechanisms in place to improve the work environment and remuneration methods to retain senior and skilled academicians. Generally, based on the above findings the researchers were forward the possible recommendation and future research direction.
\end{abstract}

Keywords: Turnover Intention, Personal factors, Internal factors, External factors, Academic Staff

\section{INTRODUCTION}

It Bonga University is one of the fourth generation Universities located in South Western Ethiopia. It was established in 2016 G.C and consists of five colleges; currently 295 academic staff were working in different departments. Intention to turnover refers to an individual's perceived probability of staying or leaving an employing organization, (Cotton and Tuttle define, 1986). Solomon (2000) concludes that the government's response to the brain drain appears coercive in its nature, Empirical results of the aforementioned authors revealed that due to insufficient salaries and poor incentive systems the academic staff in public universities of Ethiopia are forced to quit the academic arena and engage in private consultancy or extra teaching to supplement their meagre salaries.

In line with this Damtew (2004) reaffirmed that the principal serious challenges facing many African countries is the departure of their calibre workforce and scientists away from universities either in the form of internal mobility or brain drain. Ethiopian Universities are also stormed by circumstances aforementioned. Even though legislations of the universities provide university teachers need to allocate $25 \%$ of their total time for research work, many academic staff members are not involved in research and studies as part of their assignments (Teshome, 2004).

The importance of employees to an organisation has been acknowledged for a long time, as they play a pivotal role in creating and maintaining a competitive advantage for their organisations. According to Herzberg (2005), that the issue of attracting and retaining highly qualified employees stems from a managerial perspective that is more important than ever previously.

Benedict, et al., (2012) defined Labor turnover as the rate at which an employer gains and losses employees. Simple ways to describe it are "how long employees tend to stay in the organization". Employee turnover is defined as "the rate at which employees enter and leave a company in a given fiscal year."

Turnover is viewed as a voluntary cessation of membership of an organization by an employee of that organization. It results from a combination of working conditions, organizational and psychological factors interacting with each other to affect employee attitudes in and toward the organization (Bernardo et al., 2012). Public Universities are operating in a highly 
competitive environment which requires them retain their employees in order to get competitive advantage (Ng'ethe JM, 2012). The unique nature of universities expects them to be a repository of the most specialized and skilled intellectuals. They serve as storehouses of knowledge for nurturing the manpower needs of the nation.

Human resource is considered the centres of all development processes of economy and today's competitive business scenario is deteriorating social conditions of human resources, hence causing employee turnover (Shukla, and Sinha, 2013). The number and quality of academic staff makes the difference in university education. As a result, higher education institutions are more dependent on the intellectual and creative abilities and commitment of the academic staff than most other organizations. This makes it critically important to retain this cadre of staff (Ng'ethe JM, 2012, Michael O et al., 2013).

Therefore, the general objective of the study was to analyses the major determinants of turnover intention among the academic staff in Bonga University with specific objectives of identifying personal factors, internal and external factors that creates turnover intention in case of Bonga University.

\subsection{Conceptual Framework}

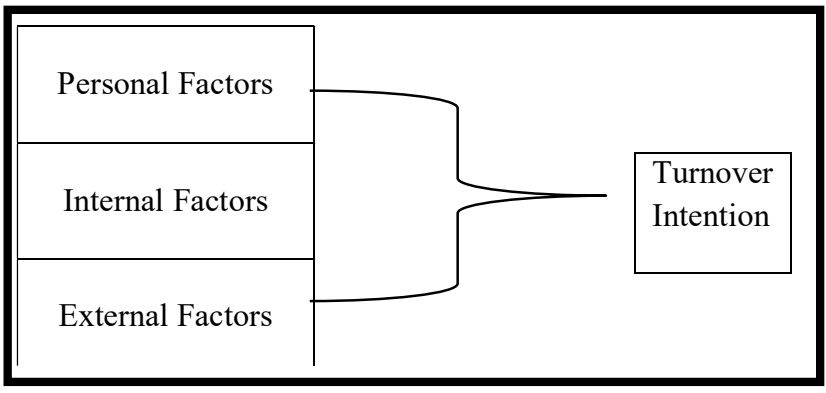

\section{RESEARCH METHODOLOGY}

Research designs are plans and procedures for research that span the decisions from broad assumptions to detailed methods of data collection and analysis (Creswell, 2009). The function of research design is to provide the collection of relevant evidence with minimal expenditure of effort, time and money (Kothari, 2004).

The research design employed in this study is both descriptive and explanatory type of research design. This research design method is adopted to show the relationship among the variable with the aid of closed ended questionnaires to analyses using descriptive statistics. The researcher used both primary and secondary data sources. The primary data were gathered by using adopted questionnaire from different studies such as
Abdali (2011), Shah, et al., (2010), Anthony, et al., (2006) and modified by the researcher in order to relate it with the specific objective of the research.

"A sample design is a definite plan for obtaining a sample from a given population" (Kotarri, 2004). Since there are many limitations such as time and budget to include the total population in the study, it is necessary to take sample from the total population under study. For this study, the researcher has used optimal sample size that is not too large sample size to be in line with available resource and time and too small sample size, which may not represent the total population. Therefore, appropriate sample size has to be applied in order to get good representative data.

The sampling method for the target population used simple random sampling. In random sampling, each individual in the population has an equal probability of selected which is important for the external validity of the study (Creswell, 2009). Accordingly, the total study population 295 in the Bonga Univeristy and Sample size of 157 respondents is taken from Academic Staff of Bonga University. To calculate sample size, simplified formula provided is used i.e. $\mathrm{n}=$ $\mathrm{N} / 1+\mathrm{N}$ (e) $2=170$, Where; " $\mathrm{n}^{\text {ecee }}$ is the sample size, " $\mathrm{N}$ "eee is the population size and "e $\mathrm{e}^{\text {ece }}$ is the level of precision is $5 \%$.

Correlation coefficient is a perfect positive linear relationship if it is positive and is a perfect negative linear relationship if it is negative (Hair, Bush \&Ortinau, 2006). Meanwhile, if obtain zero for this analysis, then it indicates as no relation. Moreover, correlation coefficient that ranges from 0.20 to 0.40 are indicated as weak relationship; range from 0.40 to 0.60 is indicated as moderate relationship, whereas the range from 0.60 and above is indicated as strong relationship of correlation coefficient.

Reliability refers to the degree to which a set of variables are consistent with what they are intended to measure (Hacker et al., 2003). Accordingly, the reliability of the study survey is dependent on the extent of respondent's turnover intention. The reliability of this research study was categorized under three determinant factors, which was computed by Cronbach Alpha value using statistical package for social scientists (SPSS) version 23 Software. According to Hair, et al., (2006), if $\alpha$ is greater than 0.7 , it means that it has high reliability and Multiple Linear Regression models to determine the significance level of the variables for the Turnover intention determinants.

\section{RESULT AND DISCUSSION}

\subsection{Background Characteristics of Respondents}


A total of 157 academicians responded to the questionnaire. The majority of study participants, $(73.1 \%)$ were males and $(26.9 \%)$ females. $(13.4 \%)$ of study participants fall in the age group of $20-30,(86.6 \%)$ fall into the age group of 31-40. $(65.7 \%)$ of respondents were Single and $(34.3 \%)$ were married, $(13.4 \%)$ of the respondents' degree and $(86.6 \%)$ were master, $(13.4 \%)$ of the respondents' salary range $5001-8000$ and $(86.6 \%)$ were salary range $8001-12,000$, (16.4\%) were service year below 1 years, $(53.7 \%)$ were service year between $1-2$ years, $(22.4 \%)$ and $(7.5 \%)$ were above 3 years.

\section{Descriptive Statistics of Turnover Intention}

\begin{tabular}{|l|l|l|l|l|}
\hline & N & Min. & Max. & Mean \\
\hline $\begin{array}{l}\text { As soon as I can find a better job I } \\
\text { will quit this university }\end{array}$ & 157 & 1 & 5 & 3.90 \\
I often think about quitting my job & 157 & 1 & 5 & 3.52 \\
$\begin{array}{l}\text { I intend to leave the university } \\
\text { within the next 12 months }\end{array}$ & 157 & 1 & 5 & 2.91 \\
$\begin{array}{l}\text { I will probably look for a new job/ } \\
\text { transfer next year }\end{array}$ & 157 & 1 & 5 & 3.43 \\
Valid N (list wise) & 157 & & & \\
\hline
\end{tabular}

Analysis of Turnover Intention items, as soon as I can find a better job I will quit this university has mean score of 3.90 . This indicates that most of the Academic Staff has quit their job after getting better jobs and weak mean on intending to leave university within the next 12 months.

\section{Inferential Findings}

In this research were conducted the reliability test using the Cronbach's alpha in order to identify the consistency of the items in the data instrument.

The reliability coefficient applied in this research allowed to identify the stability, consistency and also enhance the accuracy of assessment of the data instrument used in this research and it coefficient varies between 0 and 1 (Tavakol and Dennick, 2011), where Bryman and Bell (2011) considered acceptable internal reliability when greater than 0.80 , and others authors considered as excellent internal reliability when the Cronbach's alpha is greater than 0.9 , good between 0.8 and 0.9 , acceptable between 0.7 and 0.8 , questionable between 0.6 and 0.7 , and the others results lower than 0.5 can be explained by a low number of items, poor inter-relatedness between items or heterogeneous constructs. Analysing the three constructs of factors have acceptable and also the items of turnover intention.
Table 2: Reliability and Sample Characteristic

\section{Reliability Statistics}

\begin{tabular}{|l|l|l|}
\hline \multirow{2}{*}{ Determinants } & N of Items & $\begin{array}{l}\text { Cronbach's } \\
\text { Alpha }\end{array}$ \\
\hline Personal Factors & 9 & 789 \\
\hline Internal Factors & 14 & 880 \\
\hline External Factors & 8 & 775 \\
\hline Intention & 4 & 727 \\
\hline
\end{tabular}

Correlation matrix is used in this study to show the strength of relationship among variables considered in the hypothesis. The correlation matrix further indicates that all Turnover intention determinants were positively correlated with Turnover Intention.

Person Correlation analysis Correlations

\begin{tabular}{|c|c|c|c|c|c|}
\hline & Personal & Internal & External & Intention \\
\hline Personal & $\begin{array}{l}\text { Pearson } \\
\text { Correlation } \\
\text { Sig. (2-tailed) } \\
\mathrm{N}\end{array}$ & 157 & $\begin{array}{l}.714 * * \\
.000 \\
157\end{array}$ & $\begin{array}{l}.681^{* *} \\
.000 \\
157\end{array}$ & $\begin{array}{l}.543 * * \\
.000 \\
157\end{array}$ \\
\hline Internal & $\begin{array}{l}\text { Pearson } \\
\text { Correlation } \\
\text { Sig. (2-tailed) } \\
\mathrm{N}\end{array}$ & $\begin{array}{l}.714 * * \\
.000 \\
157\end{array}$ & 157 & $\begin{array}{l}.826^{* *} \\
.000 \\
157\end{array}$ & $\begin{array}{l}616^{* *} \\
.000 \\
157\end{array}$ \\
\hline External & $\begin{array}{l}\text { Pearson } \\
\text { Correlation } \\
\text { Sig. (2-tailed) } \\
\text { N }\end{array}$ & $\begin{array}{l}681^{* *} \\
.000 \\
157\end{array}$ & $\begin{array}{l}826^{* *} \\
.000 \\
157\end{array}$ & 157 & $\begin{array}{l}681^{* *} \\
.000 \\
157\end{array}$ \\
\hline Intention & $\begin{array}{l}\text { Pearson } \\
\text { Correlation } \\
\text { Sig. (2-tailed) } \\
\mathrm{N}\end{array}$ & $\begin{array}{l}.543 * * \\
.000 \\
157\end{array}$ & $\begin{array}{l}616^{* *} \\
.000 \\
157\end{array}$ & $\begin{array}{l}681^{* *} \\
.000 \\
157\end{array}$ & 157 \\
\hline
\end{tabular}

**. Correlation is significant at the 0.01 level (2-tailed).

\section{Multiple Regression Analysis}

In this part of the analysis includes a regression model to test the hypotheses. Three extracted determinants were taken as independent variables against turnover intention of the academic staff as dependent variable in a multiple regression model. For all the hypotheses of the study below hypothesis test was used at $95 \%$ confidence level. 


\section{Coefficientsa}

\begin{tabular}{|ll|l|l|l|l|l|}
\hline \multirow{2}{*}{ Model } & \multicolumn{2}{|l|}{$\begin{array}{l}\text { Unstandardized } \\
\text { Coefficients }\end{array}$} & $\begin{array}{l}\text { Standardized } \\
\text { Coefficients }\end{array}$ & & \\
\cline { 2 - 5 } & $\mathrm{B}$ & Std. Error & Beta & $\mathrm{t}$ & Sig. \\
\hline $1 \quad$ (Constant) & .068 & .455 & & .150 & .882 \\
& Personal & .149 & .174 & .115 & .860 & .393 \\
Internal & .151 & .235 & .112 & .644 & .522 \\
External & .682 & .221 & .511 & 3.083 & .003 \\
\hline
\end{tabular}

a. Dependent Variable: Intention

Unstandardized coefficients indicated how much the dependent variable varies with an independent variable, when all other independent variables are held constant. The beta coefficients with significant $p$ value $<0.05$ indicated that how and to what extent determinants such as personal factors, Internal factors and External factors influence turnover intention of academic staff in Bonga University. Hence, it concluded that External factors only significant impact on turnover intention others factors not influence turnover intention of academic staff at Bonga University.

\section{CONCLUSION AND RECOMMENDATION}

This study revealed that the proportion of academic staff turnover intention was found to be personal and internal factors are weak determinants on turnover intention but external factors high factors on turnover intention. There should be staff retention mechanisms in place such as improving among external factors; maximizing academic programs and working conditions, working with city administration in order to facilitate better living and recreation centres, solving house problem staff and facilitating good education for children.

These factors are useful indicators of actual turnover and provide an opportunity to take actions that might prevent realization of those intentions. Bonga University should value and recognize academic staff for their contribution by using a variety of mechanisms such as providing feedback, social and material recognition. The University should also take measures that could support academic staff by sharing fruits and burdens in work areas and expanding their good internal values and organizational cultures. Future researchers could include other variables which are not included under this study.

\section{REFERENCES}

[1] Abbasi, S.M., \& Hollman, K.W. (2000). "Turnover: The Real Bottom Line", Public personal Management, Vol 29, No 3: pp $333-342$

[2] Alemseged Tadesse, 2015, Determinants of turnover intentions of Employees; The case of Ministry of Agriculture. (Masters Dissertation). Addis Ababa University College of Management Information and Economic sciences, Addis Ababa, Ethiopia

[3] Alexander J, Bloomme J, and Nuchols B. (1994) Nursing turnover and hospital efficiency: an organization-level analysis. Industrial Relations.33 (4). pp. 505-520.

[4] Ali, Qadar Bakhsh Baloch, 2007. 'Impact of Job Satisfaction on Turnover Intention: An Empirical Evidence' Journal of Managerial Sciences Volume II, Number 1

[5] Asmamaw Argeta, (2011). Professional Employee Turnover and Retention Practice of Ethiopian Public Sector Organization of Ministry of Finance and Economic and Devolvement (MoFED), (Masters Dissertation). Addis Ababa University College of Management Information and Economic sciences, Addis Ababa, Ethiopia

[6] Creswell, J. W., (2009), Research design: Qualitative, Quantitative, and Mixed Methods Approaches, 3rd ed, USA, SAGE Publication

[7] Endalkachew Tibebu, 2015, Factors of Employee Turnover Intention in MOHA Soft Drinks Industry S.C Teklehaimanot plant. (Masters Dissertation). Addis Ababa University College of Management Information and Economic sciences, Addis Ababa, Ethiopia

[8] K. John. \& Zerihun A. (2014). The Impact of Organizational Climate Factors on Turnover Intention of Academic Staff in Central and Western Ethiopian Public Universities. International Journal of Multidisciplinary Management Studies, 4(12), 80-91

[9] Kothair, C.R., (2004), Research Methodology: Methods and Techniques, 2nd revised ed, New Age International (P) Ltd., Publishers Published by New Age International (P) Ltd, India

[10] Tewfik Abdella, 2015, Determinants of Turnover in terms of Intention to Leave on NIB Bank S.C. (Masters Dissertation). Addis Ababa University College of Management Information and Economic sciences, Addis Ababa, Ethiopia

[11] Wyaswa, F., \& Katana G. (2008). Academic Staff Perspectives on Operating Beyond Industrial Actions for Sustainable Quality Assurance in Public Universities in Kenya. International Journal of Environment, 4(1), 45-58. https://doi.org/10.1504/ijewe.2008.022257

[12] Yuen-On Choong et al., (2013). Impacts of Demographic Antecedents toward Turnover Intention amongst Academic Staff in Malaysian Private Universities. Australian Journal of Basic and Applied Sciences, 7(6), 46-54.

[13] ZewdnehTegegne, 2015 Assessment of Employee Turnover; The case of Sheraton Addis Luxury Collection Hotel. (Masters Dissertation). Addis Ababa University College of Management Information and Economic sciences, Addis Ababa, Ethiopia. 